Karolina Kramkowska*

Bydgoszcz

\title{
Poszukiwania sensu życia w rodzinie osoby doświadczającej przewlekłych chorób demencyjnych mózgu
}

Choroby demencyjne mózgu obok innych chorób przewlekłych stanowią problem rozpatrywany zazwyczaj w perspektywie medycznej samego pacjenta. Psycho-fizyczno-duchowa natura człowieka wskazuje, że problem choroby przewlekłej nie dotyczy tylko fizjonomii czy psychiki, jak również aspektów duchowych chorego, ale także całego systemu rodzinnego, w którym jest on osadzony. Zaawansowany stan choroby ostatecznie prowadzić może do utraty zdolności panowania nad własnym życiem i zależności od osób trzecich. Dla rodziny osoby chorej na demencję przebieg choroby staje się destrukcyjny ze względu na jej długotrwałość oraz złożony charakter. Wobec trudów opieki pojawić się mogą pytania o sens własnego działania, cierpienia i ostatecznie sens życia podopiecznego, ale także opiekunów rodzinnych. Kryzys psychoemocjonalny opiekunów przejawia się nie tylko w podwyższonej wrażliwości aksjologicznej, ale także w traceniu poczucia sensu własnego życia, zarówno w toku sprawowanej opieki, jak i po śmierci chorego. Wsparcie środowiskowe może skutecznie przywracać poczucie

* Mgr Karolina Kramkowska, jest doktorantką na Wydziale Pedagogiki i Psychologii Uniwersytetu Kazimierza Wielkiego w Bydgoszczy. Adres: Wydział Pedagogiki i Psychologii Uniwersytetu Kazimierza Wielkiego w Bydgoszczy, ul. Jana Karola Chodkiewicza 30, 85-064 Bydgoszcz; e-mail: karolinakramkowska@gmail.com. 
celu oraz życiowego sensu opiekunom rodzinnym osób chorych na demencje. Zagadnienie to zostanie przedstawione w niniejszym artykule.

\section{Choroby demencyjne mózgu - charakterystyka zjawiska}

Podejmując się analizy wartości i poczucia sensu życia w rodzinie doświadczającej przewlekłych chorób demencyjnych mózgu, należy rozpocząć od wyjaśnień terminologicznych badanych zagadnień. Choroby demencyjne mózgu to schorzenia będące następstwem demencji i zespołu otępiennego bądź ściśle z nimi powiązane. Za światową Organizacją Zdrowia należy stwierdzić, że zespół otępienny to:

zespół objawów wywołany chorobą mózgu, zwykle przewlekłą lub o postępującym przebiegu, charakteryzujący się klinicznie licznymi zaburzeniami wyższych funkcji korowych, takich jak pamięć, myślenie, orientacja, rozumienie, liczenie, zdolność do uczenia się, język i ocena. Ponadto zaburzeniom funkcji poznawczych często towarzysza, lub nawet je poprzedzają, zaburzenia emocjonalne, zaburzenia zachowania i motywacji. Takiemu obrazowi mogą nie towarzyszyć zaburzenia świadomości. Zaburzenia świadomości przy występowaniu demencji stanowią odrębną kategorię diagnostyczną ${ }^{1}$.

W literaturze anglojęzycznej wszystkie te schorzenia określa się terminem demencja (dementia).

Rodzina, będąca przedmiotem badań wielu nauk, w tym nauk społecznych i o wychowaniu, posiada liczne definicje. Wciąż aktualny jest opis autorstwa Augusta Comte'a definiujący ,rodzinę jako podstawową komórkę społeczną" ${ }^{2}$. Szczegółowe zdefiniowanie rodziny nie jest łatwe ze względu na wielość definicji i ujęć w literaturze przedmiotu, wskazujących na różnorodne ujęcia jej składu personalnego oraz cech relacji osób w niej będących. Zbigniew Tyszka nazywa rodzinę: podstawową grupą społeczną złożoną z rodziców i dzieci, które cechuje więź formalna, wspólnota materialna i mieszkaniowa oraz funkcje przez nich spełniane: prokreacyjna, społecz-

1 World Health Organization, Alzheimer's Disease International, Dementia - a public health priority (Genewa: World Health Organization, 2012).

2 Zbigniew Tyszka, „Rodzina w świecie współczesnym - jej znaczenie dla jednostki i społeczeństwa”, w: Pedagogika społeczna, red. Tadeusz Pilch, Irena Lepalczyk (Warszawa: Żak, 1995), 137. 
na, kulturalna, gospodarcza ${ }^{3}$. Maria Ziemska uważa natomiast, że rodzina stanowi całość względnie trwała, podlega dynamicznym przekształceniom i związana jest głównie z biegiem życia jednostek wchodzących $w$ jej skład ${ }^{4}$. Aktualny namysł nad rodziną w zmieniającej się rzeczywistości życia rodzinnego podejmuje Tomasz Biernat, podkreślając, że wartym zauważenia jest fakt opisu rodzin w oficjalnych dokumentach Unii Europejskiej, gdzie stosuje się szerokie i wieloznaczne określenie ,życie rodzinne”. Jego zdaniem powinno się mówić raczej o rodzinach niż rodzinie, a rozszerzanie definicji rodziny nie jest tylko zabiegiem formalnym, lecz odzwierciedleniem dokonujących się przemian społecznych związanych z rodziną ${ }^{6}$. Zauważalne jest odchodzenie od definicji esencjalistycznych tworzonych na podstawie prawa naturalnego i definicji normatywnych wywodzących się z nauki (socjologia, antropologia), a także przechodzenie do definicji konstruktywistycznych, inkluzywnych. Włączają one w swój szeroki zakres różne formy życia rodzinnego, w których występuje jakaś forma „rodzinności”. Niektórzy badacze wręcz stwierdzają że obecnie, ze względu na wiele postaci rodziny, nie ma możliwości sformułowania jednej uniwersalnej definicji rodziny (tyle definicji, ile rodzin) ${ }^{7}$. Na potrzeby tego artykułu przyjęta zostanie szeroka definicja rodziny, obecna w literaturze przedmiotu, gdzie rodzinę rozumie się jako „duchowe zjednoczenie szczupłego grona osób skupionych we wspólnym ognisku domowym aktami wzajemnej pomocy i opieki, oparte na wierze w prawdziwą lub domniemaną łączność biologiczną, tradycję rodzinną i społeczną".

Opisane wyżej choroby demencyjne dotykają nie tylko pojedyncze osoby, ale całe rodziny, które stanowią tym samym naturalne tło dla zmagań $\mathrm{z}$ chorobami przewlekłymi, szczególnie w warunkach domowych. Z przeprowadzonych przez Eurofamcare badań w Polsce w latach 2003-2004 oszacowano liczbę osób zaangażowanych w opiekę (opiekunów nieformalnych)

${ }^{3}$ Zbigniew Tyszka, Socjologia rodziny (Warszawa: PWN, 1974), 54.

${ }^{4}$ Maria Ziemska, Rodzina a osobowość (Warszawa: Wiedza Powszechna, 1979), 76.

5 Por. Tomasz Biernat, „O przemianach definicji rodziny i ich konsekwencjach”, Spoteczeństwo i Rodzina 18 (2009): 33.

${ }^{6}$ Por. Tomasz Biernat, „Czy istnieje rodzina ponowoczesna?”, Pedagogia Christiana 2 (2014): 187-188.

7 Tamże, 188 .

${ }^{8}$ Sebastian Jakubiec, Mediacje jako metoda pracy z rodzina (Kraków: WSFP Ignatianum, 2011), 7 - cyt. za: Franciszek Adamski, Rodzina, wymiar społeczno-kulturowy (Kraków: Wydawnictwo Uniwersytetu Jagiellońskiego, 2002), 31. 
na około $2 \mathrm{mln}$ osób9 . Członkowie rodziny są zazwyczaj najbliższymi osobami dla chorego i zaspokajają większość jego potrzeb, zarówno w zakresie czynności pielęgnacyjno-opiekuńczych, jak i podstawowej potrzeby akceptacji oraz bycia kochanym. Środowisko rodzinne pozwala na pełniejsze zaspokojenie potrzeby bezpieczeństwa i jest substytutem życia społecznego. Demencje, ze względu na rosnącą liczbę osób chorych na całym świecie, szacowane są na ponad 47,5 mln, a prognozowane na 75,6 milionów osób dotkniętych tymi schorzeniami w 2030 roku i na potrojenie się dzisiejszej liczby w roku $2050^{10}$. W Polsce liczbę osób chorych na choroby demencyjne szacuje się od $5,7-10 \%$ społeczeństwa ${ }^{11}$.

Demencje są poważnym i rosnącym problemem zdrowotnym oraz społecznym, dotykającym rodziny. Pomimo możliwości pełnego diagnozowania chorób otępiennych mózgu, a także pomocy osobom, u których to schorzenie jest stwierdzone, praktyka pracy z rodzinami chorych wskazuje, iż wiele osób nie ma świadomości pierwszych jej objawów. Określa się je często jako „normalne dla starzenia”, gdy są one stanami chorobowymi możliwymi do leczenia dla podniesienia komfortu życia pacjenta i jego rodziny. Do właściwej diagnozy, także w obszarze rodzinnym, przydatne są podstawowe kryteria diagnostyczne wskazane przez Amerykańskie Towarzystwo Psychiatryczne (APA), takie jak: obecność wielu deficytów poznawczych (upośledzenie pamięci), afazja (zaburzenia mowy), apraksja (zaburzenie zdolności do wykonywania czynności ruchowych), agnozja (percepcyjne zaburzenia rozpoznawania) oraz zaburzenia funkcji wykonawczych (planowania, organizacji, porządkowania i/lub abstrakcyjnego myślenia), które obrazuja, w jak wielu aspektach choroba ta upośledza funkcjonowanie osoby chorej w aspekcie samoobsługi i funkcjonowania społecznego ${ }^{12}$. Zaawanso-

9 Anna Janowicz, „Rola opiekunów nieformalnych w opiece u kresu życia. Przyczynek do badań w ramach projektu European Palliative Care Academy (EUPCA)", Pielęgniarstwo i Zdrowie Publiczne 2 (2014): 161-167.

${ }^{10} \mathrm{http} / /$ www.who.int/features/factfiles/dementia/en/ [dostęp: 09.2015].

${ }^{11} \mathrm{~W}$ odniesieniu do statystyk należy mieć na uwadze, że sporządzane są one w oparciu o dane dotyczące liczby chorych powyżej 65 . roku życia, zdiagnozowanych w danym schorzeniu lub podejmujących leczenie, tu liczba ta jest szacowana na 300.000 do 500.000 osób chorych, ale liczba osób z chorobą Alzheimera może być znacznie większa. Por: Rzecznik Praw Obywatelskich, Sytuacja osób chorych na chorobę Alzheimera w Polsce, https://www.rpo.gov. $\mathrm{pl} /$ sites/default/files/Sytuacja $\% 20$ os $\%$ C3\%B3b\%20chorych\%20na\%20chorob\%C4\%99\%20 Alzheimera\%20w\%20Polsce\%20Raport\%20RPO.pdf [dostęp: 12.2015 r.].

${ }_{12}$ Maria Barcikowska, Rozpoznawanie i leczenie otęień. Rekomendacje Interdyscyplinarnej Grupy Ekspertów Rozpoznawania i Leczenia Otępień (Lublin: Igero, 2006), 12-13. 
wany stan choroby ostatecznie prowadzić może do utraty zdolności panowania nad własnym życiem oraz zależności od osób trzecich. Dla rodziny proces chorobowy jest nie mniej destrukcyjny jak dla samego chorego ze względu na fakt, iż sprawowanie opieki nad osobą niesamodzielną z ograniczoną świadomością wiąże się z koniecznością wprowadzenia wielu zmian w życiu opiekunów rodzinnych. Zarówno członkowie rodziny, jak i inne bliskie osoby sprawujące opiekę - przyjaciele, znajomi, sąsiedzi, członkowie wspólnot religijnych, wolontariusze, itp. - są określani terminem „opiekun nieformalny”, dla odróżnienia od opiekunów związanych formalnymi zobowiązaniami profesji pomocowej i umowy o pracę ${ }^{13}$.

Podstawowe problemy opiekunów nieformalnych osoby z chorobą demencyjną to: wyobcowanie społeczne opiekunów, niedostateczna wiedza na temat diagnostyki i następstw chorób demencyjnych, poczucie winy związane z nieadekwatnością nakładu pracy opiekuńczej do efektu, bezradność wobec piętrzących się problemów oraz ostatecznie wypalenie opiekuńcze ${ }^{14}$. Dla opiekunów rodzinnych i innych bliskich osób, poza problemem tabuizacji chorób mózgu i chorób psychicznych, dużym problemem jest pogarszający się stan podopiecznego, pomimo dużego nakładu pracy opiekuńczej. Dużym obciążeniem dla opiekunów rodzinnych jest emocjonalne tracenie osoby bliskiej, która niejednokrotnie nie rozpoznaje osób bliskich, pozostając z nimi w zewnętrznej relacji. Obciążające jest także poczucie nieuchronności śmierci, unaoczniające się przez pogarszający się stan bliskiej osoby.

Problemy, z jakimi spotyka się rodzina, prowadzić mogą do jej dysfunkcjonalności, która może dotyczyć zakresu realizowanych w niej zadań. Problemy mogą wynikać z niepowodzeń w realizacji zadań wychowawczych, walki z kryzysem w małżeństwie, niepowodzeń w zaspokojeniu potrzeb osoby chorej lub zaniedbanie zadań oraz różnych sfer życia rodzinnego ${ }^{15}$. Długoletnia, a w wielu przypadkach całodobowa, opieka nad chorym może wpływać destrukcyjnie na funkcjonowanie rodziny. Brak czasu na budowanie i podtrzymywanie prawidłowych relacji z dziećmi, w małżeństwie oraz szeroko pojętej rodzinie w konsekwencji prowadzić może do zaburzenia zaspokojenia potrzeb jej członków. Skutkiem może być także zaniedbywanie

${ }_{13}$ Por. Piotr Krakowiak, Wolontariat w opiece u kresu życia (Toruń: Wydawnictwo Naukowe Uniwersytetu Mikołaja Kopernika, 2012), 23.

${ }_{14}$ Por. Bożena Grochmal-Bach, Cierpienie osób z otępieniem typu Alzheimera (Kraków: WAM, 2007).

15 John Bradshaw, Zrozumieć rodzinę (Warszawa: IPZiT, PTP, 1994), 81. 
ciężko chorej osoby, gdyż - jak zauważa Iwona Kłoszewska - poczucie obciążenia może stać się źródłem niechęci wobec chorego ${ }^{16}$. Całodobowa opieka, brak snu i nadmiar obowiązków sprzyjają zmęczeniu, a nawet depresji u opiekunów rodzinnych ${ }^{17}$.

Dla chorego bardzo trudnym aspektem choroby jest poczucie bezradności i lęku związane z pogarszającą się możliwością samodzielnego funkcjonowania, a także obawa przed byciem ciężarem dla rodziny ${ }^{18}$. Na drugim biegunie znajdują się poczucie bezradności wobec cierpienia bliskiej osoby oraz nieustanny lęk przed jej odejściem. Potwierdzeniem dramatycznego położenia opiekuna jest wypowiedź córki kobiety z chorobą Alzheimera.

Mama zawsze była dla nas najbliższą osobą, dbała o nas, o wykształcenie i to, żebyśmy wyrośli na dobrych ludzi. Jako dorośli też jesteśmy zżyci wszyscy ze sobą i mama to wszystko scalała, robiła święta, odwiedziny, dużo by mówić. Teraz to wszystko nie ma sensu, nie wiem jak mam zrobić święta bez mamy, a ona na pewno nie wyjdzie ze szpitala. Płakać mi się chce jak tylko o tym myślę. Nikt nie rozumie, jak tego nie przeżył, że się nie da tak żyć, bo wszystko jest bez sensu i tak myślami jest się z mamą. Nie wyobrażam sobie, jak mama umrze $^{19}$.

Często pojawiają się skrajne emocje towarzyszące opiekunom rodzinnym, a perspektywa rozstania zaburza lub odbiera sens ich życia. Stąd zasadne zarówno z perspektywy filozoficznej, jak również dla potrzeb praktyków opieki nad osobami u kresu życia i pedagogów jest wskazanie zarówno definicji sensu życia, ale też kierunków jego poszukiwania w kryzysie tego schorzenia.

${ }^{16}$ Iwona Kłoszewska, „Rola opiekuna chorych z otępieniem”, Polski Przeglad Neurologiczny 2 (2007): 105-109.

17 Jan Terelak, „Przeciążenie jako źródło stresu”, w: Psychologia stresu, red. Jan Terelak (Bydgoszcz: Oficyna Wydawnicza BRANTA, 2001), 190-194.

18 Por. Tomasz Gabrylewicz, „Konsekwencje zdrowotne i społeczne łagodnych zaburzeń poznawczych", w: Choroby otępienne. Teoria i praktyka, red. Jerzy Leszek (Wrocław: Continuo, 2003), 365.

19 Fragment wiadomości przesłanej do autorki bloga dla opiekunów osób chorych na demencje, cyt. za: opiekanadseniorami.blogspot.com, redakcja bloga: K. Kramkowska. 


\section{Opieka nad chorym na demencje a sens życia i jego poszukiwanie}

Oksfordzki słownik filozoficzny definicyjnie wiąże sens życia (ang. meaning of) z jego celem:

Niemal dla każdego ważne jest, czy jego życie ma jakiś cel. Ale cele bywają różne: cel życia jednej osoby może polegać na osiągnięciu czegoś, gdy tymczasem celem życia innej będzie zdobycie czegoś całkowicie odmiennego. Wcale nie musi być tak, że istnieje tylko jedna rzecz, która jest dla każdego celem życia. [...] Podobnie większość ludzi będzie usatysfakcjonowana, jeżeli w każdym momencie życia będą mieli coś, do czego mogą dążyć, i wcale nie musi być tak, że w każdym z tych momentów mają dążyć do tego samego ${ }^{20}$.

$\mathrm{Na}$ gruncie polskim filozoficzne rozważania na temat sensu prowadzili przedstawiciele szkoły lwowsko-warszawskiej Tadeusz Czeżowski i Tadeusz Kotarbiński oraz Józef Maria Bocheński. Kotarbiński uważał, że określenie sensu życia ważne jest dla człowieka, by swoje własne czyny mógł on ocenić jako ważne i warte poświęconego zaangażowania: „Kto szuka sensu życia szuka tego samego właśnie, o to jest zatroskany, by jego czyny nie były bezcelowe, a ściślej, by jego działalność nie wyczerpywała się w błahych przedsięwzięciach, lecz mogła się legitymować przydatnością do celu godnego poświęcenia mu głównych, najważniejszych wysiłków”21.

W przypadku opiekunów rodzinnych to właśnie opieka nad osobą bliską staje się tym „głównym, najważniejszym wysiłkiem” i to w niej niejednokrotnie dostrzegają sens własnego życia w aspekcie oddania siebie bliskiej osobie. Sens upatrują również w budowaniu relacji z osobą chorą, w maksymalnym wykorzystaniu czasu, jaki pozostał w jej życiu. Mimo iż wszystkie czyny ludzkie w mniejszym lub większym stopniu określają sens życia człowieka, dopiero w sytuacji egzystencjalnie trudnej dla niego pojawiają się refleksja i pytania o sens życia. Pytanie o sens ujmuje się w kategoriach pytań egzystencjalnych i jest ono kluczowym pytaniem w wielu koncepcjach filozoficznych i duchowo-religijnych. Zagadnienie sensu życia jest szczególnie

${ }^{20}$ Simon Blackburn, Oksfordzki słownik filozoficzny (Warszawa: Książka i Wiedza, 1997), 463.

${ }^{21}$ Tadeusz Kotarbiński, Medytacje o życiu godziwym (Warszawa: Wiedza Powszechna, 1966), 2. 
bliskie człowiekowi ze względu na swój transcendentalny i egzystencjalny charakter. Pomimo tej oczywistości powiązania człowieka z pytaniem o sens nie rodzi się ono często w codziennym życiu, a refleksji w tym zakresie doświadczamy zazwyczaj w obliczu sytuacji trudnej. Dzieje się tak ze względu na specyfikę samego życia i jego składowych: aktywnej, gdy kreujemy i działamy oraz pasywnej, gdy poddawani jesteśmy biegowi życia. Każde działanie uwzględnia okoliczności, na które mamy wpływ, i te, na które go nie mamy ${ }^{22}$. Pojawia się pytanie o sens tego, w co człowiek angażuje się emocjonalnie, sens jego aktywności i ostatecznie o sens życia własnego $i$ innych ludzi. Także w perspektywie duchowej i religijnej pytania o sens życia są odwiecznymi domenami zarówno myśli filozoficznej, jak i działań pastoralnych, co przypomniał Benedykt XVI w encyklice Spe Salvi ${ }^{23}$. Choroba i cierpienie najbliższej osoby w kręgu rodzinnym jest wyzwaniem dla świata wartości, często poddawanego próbie poprzez bezradność i trudy opieki. Niejednokrotnie spokojne życie bezpowrotnie zmienia swój bieg i trudno odnaleźć sens w nowych trudnych sytuacjach. Refleksja aksjologiczna związana jest przede wszystkim z postawieniem człowieka w sytuacji, na którą nie ma bezpośredniego wpływu. W sytuacji, gdy życie toczy się biegiem pomyślnym dla jednostki, nie ma ona potrzeby definiowania tego, co składa się na jej życie, a także wzbudzania refleksji nad sytuowaniem siebie w świecie wartości. Sytuacja trudna, jaką jest zmaganie się z chorobą osoby bliskiej, brak wpływu na przebieg i finał choroby stają się katalizatorami pytań o sens życia własnego, przemijanie i życie po śmierci. Pytanie to zawsze osadzone jest w określonym przez jednostkę systemie wartości, bez względu na to, czy dana jednostka ma świadomość wyznawanych wartości, czy też nie.

Korzystając z dorobku filozofii i psychologii egzystencjalnej, można zauważyć, że nie ma jednolitej koncepcji celu i sensu. W historii filozofii pojawiały się koncepcje, które wiązywały sens życia z pojęciem obowiązku (Kant, Weber), utylitaryści twierdzili natomiast, że życie ma sens wówczas, gdy przeważa w nim szczęście. W tym artykule przyjęto za Kołakowskim koncepcję, która sens życia utożsamia z celem życia ${ }^{24}$. Henryk Elzenberg

22 Cyt. za: Marek Dolata, „Sens życia jako problem etyki”, w: Etyka i sens życia, red. Dorota Probucka (Kraków: WNUP, 2011), 64.

${ }^{23}$ Benedykt XVI, Encyklika Spe Salvi (Watykan: 2007), gdzie czytamy: „Sarkofagi z początków chrześcijaństwa obrazują to pojmowanie nadziei, bowiem w obliczu śmierci pytanie o sens życia jest nieuniknione. Postać Chrystusa przedstawiają na antycznych sarkofagach przede wszystkim dwa obrazy: filozofa i pasterza" (nr 6).

${ }^{24}$ Leszek Kołakowski, Światopogląd $i$ życie codzienne (Warszawa: PIW, 1975), 174 -206 . 
polemizuje z tą myślą, niejako też dopełniając ją, twierdząc, że dążenie człowieka do celu ma znaczenie etyczne i nie ma czegoś takiego, jak nadawanie sensu życia poprzez działanie woli - człowiek dążyć może jedynie do celów wartościowych i w tym sensie nadaje sens życiu ${ }^{25}$. Wartościowaniu temu sprzyja wrażliwość aksjologiczna, która w rozumieniu Urszuli Ostrowskiej stanowi „zdolność człowieka do ewaluacji (wartościowania) wrażeń pochodzących ze świata zewnętrznego lub/i ze świata wewnętrznego organizmu w aspekcie zinternalizowanego systemu wartości i ich hierarchii jako podstawy zachowań podmiotu w przestrzeni aksjologicznej antroposfery"26. Umiejętność wzbudzania refleksji aksjologicznej, odpowiadanie sobie na pytania o własny system wartości w sytuacjach trudnych pomóc może opowiedzieć się i zdecydować, w jaki sposób człowiek postąpi w zgodzie z sobą samym. Ma to znaczenie także w obszarze wsparcia opiekunów osób z chorobami demencyjnymi mózgu. Postrzeganie człowieka holistycznie i pomoc w rozwiązywaniu problemów o charakterze duchowym i etycznym może przynosić trwalsze efekty w postaci postrzegania zmian i sytuacji trudnych nie jako kryzysu, ale jako kolejnego wyzwania na drodze ludzkiego życia. Pytań o sens życia, pojawiających się wśród opiekunów rodzinnych, nie powinni unikać profesjonalni opiekunowie, a szczególnie osoby odpowiadające za pozamedyczne elementy opieki - psychologowie, pracownicy socjalni, duszpasterze i inni członkowie zespołów opiekuńczych ${ }^{27}$.

Podjęcie działań opiekuńczych wobec osoby chorej również powiązane jest z określeniem celu i wartości, które ten cel określa. Opieka ta może sama w sobie stać się celem w znaczeniu: „stawiam sobie za cel, że będę opiekował się swoją matką" lub możliwe jest wyznaczenie celu w obrębie opieki: „celem mojej opieki jest podniesienie sprawności fizycznej ojca” lub cel koncentrowany na sobie: „opiekę tę podjąłem w celu nabycia umiejętności wsparcia osób starszych". Bez względu na określenie celu, osadzony jest on w wartościach, które jednostka wskazująca cel wyznaje, a także powiązany jest on ściśle ze znaczeniami, jakie nadaje jednostka sytuacji życiowej, w której się znajduje. Psychologia dysponuje wieloma teoriami dotyczącymi postrzegania świata przez człowieka. W psychologii egzystencjalnej nie zasada przyczynowości, a interpretacji jest kluczowa, więc postępowanie

${ }^{25}$ Henryk Elzenberg, Z filozofii kultury (Kraków: Znak, 1991), 378-379.

${ }^{26}$ Urszula Ostrowska, ,Aksjologiczne podstawy wychowania”, w: Pedagogika: podstawy nauk o wychowaniu, t. 1, red. Bogusław Śliwerski (Gdańsk: Gdańskie Wydawnictwo Psychologiczne, 2006), 398-399.

${ }^{27}$ Krakowiak, Wolontariat, 136. 
człowieka i jego uczucia wynikają z interpretacji obecnej sytuacji życiowej. Oznacza to, że cecha transcendentalna jednostki wyraża się w możliwości tworzenia przez nią nowych znaczeń dla zastanych sytuacji. Można zatem stwierdzić, iż to jednostka ponosi odpowiedzialność za swoje samopoczucie, bo wynika ono z jej sposobu pojmowania świata i jej wyborów.Zastanej przez człowieka sytuacji on sam nadaje sens i jest ona tym samym tak nacechowana emocjonalnie, jak on sam ją cechuje ${ }^{28}$.

Takie rozumienie sensu życia człowieka i możliwości nadawania znaczeń sytuacjom ,narzuconym przez życie” ma znaczenie dla efektywniejszego radzenia sobie z procesem zmagania się z ciężką chorobą osoby bliskiej. Umiejętność refleksji może zbudować trwały sposób radzenia sobie z trudnościami rodziny, poszukującej zbieżności wartości i celów. Wiedza o tym, kim jestem i jakie mam cele, pozwoli na pełniejsze zrozumienie nowej sytuacji, a nadawanie jej znaczeń nie musi wiązać się z kryzysem. Odpowiedzi na pytania, takie jak: jaki jest cel mojego postępowania?; jakie wartości wyznaję?; jakich wartości bronię w przypadku dylematu etycznego?; jaki jest cel mojego życia?; jaki jest sens mojego życia? - pozwolą na uporządkowanie znaczeń i wartości w życiu, pomagając w określeniu wartości zbieżnych dla pozostałych członków rodziny, zmagających się z trudami opieki. W przypadku opiekunów osób z zaburzeniami świadomości analiza wartości i namysł nad sensem pomóc mogą w określeniu, w jaki sposób postępować wobec osoby, która nie jest w stanie sama opowiedzieć się za wartościami. Pytania, które rodzi taka sytuacja - czy przyjmować jej wartości obecne, postępować wobec wartości sprzed choroby czy nadawać własne znaczenia? - kreują nowe problematyczne zagadnienie, a tym trudniejsze, im mniej opiekun zna siebie samego.

Nadawanie znaczeń ma charakter dynamiczny, podobnie jak dynamiczne są zmiany sytuacji życiowej człowieka. Bóg lub los stają się falsyfikatorem rozwiązań życiowych na bazie ludzkich dążeń. Wraz z nowymi potrzebami rodzą się nowe możliwości ich zaspokojenia, a potrzeba sensu życia uważana być może za metapotrzebę. W obliczu zmian sytuacji także nadanie nowych znaczeń może prowadzić do przewartościowania życia jednostki lub rodziny. W praktyce opiekuńczej zmiana najczęściej określana przez chorych i ich rodziny to odejście od dóbr materialnych na rzecz budowania relacji z drugim człowiekiem. To także umiejętność czerpania radości z codziennego bycia z bliskimi osobami. Bocheński zwraca uwagę

28 Piotr Oleś, Wprowadzenie do psychologii osobowości (Warszawa: Wydawnictwo PWN, 2003), 319. 
na umiar w wyborach życiowych i obranie jednego konkretnego celu, by nie dopuszczać do sytuacji wielu stawianych celów bez szans na ich osiągnięcie oraz na umiejętność cieszenia się teraźniejszością. Ważne jest również to, by wyznaczony cel był osiagalny ${ }^{29}$. Porady te są istotne dla opiekunów rodzinnych. Jak dodaje Bocheński w Sensie życia: „Życie danego człowieka ma sens wtedy lub tylko wtedy, kiedy albo istnieje cel, do którego on w tej chwili dąży, albo on tej chwili używa" ${ }^{30}$. Dążenie do celu i posiadanie go jest więc fundamentalnie wpisane w życie człowieka, ale - jak zauważa Jarosław Horowski w odniesieniu do filozofii Bocheńskiego - ,życie nie polega tylko na nieustannym dążeniu do czegoś, ale także na korzystaniu z życia, cieszeniu się życiem" "31.

W odniesieniu do nadawania sensu życia w opiece nad chorym, może być to szczególnie niebezpieczne, kiedy chory umiera, a opiekun nie potrafi czerpać radości z życia. O sytuacji braku sensu mówi wprost jeden z opiekunów, który wraz z żoną poświęcił lata opieki bliskiej osobie:

Przegraliśmy walkę, nie odzywaliśmy się, ale nie było kiedy, bo stan był już bardzo ciężki, teściowa odeszła. [...] Nie wiem, co dalej robić, niby się człowiek cieszy, że już nie cierpi, ale po tylu latach trudno się znaleźć bez opieki, bez tych obowiązków. Ja i syn jakoś sobie radzimy, ale żona jest w rozsypce i się o nią bardzo martwię [...]. Wszystko było przewrócone do góry nogami, żona z pracy zrezygnowała, całe dnie i noce tam była z nią, a nie udało się pomóc. [...] Wszystko można mieć, ale jak się zachoruje, jak nie można pomóc to się widzi, że to życie to nie ma sensu ${ }^{32}$.

Dostrzegając ładunek emocjonalnych i egzystencjalnych wyzwań rodziny borykającej się z chorobą demencyjna, należy zauważyć grupę duchowych i religijnych wartości oraz ich związek z sensem życia opiekunów rodzinnych. Zostaną one przeanalizowane w kolejnej części tego artykułu.

29 Józef Maria Bocheński, Podręcznik mąrości tego świata (Kraków: Wydawnictwo Philed, 1992), 21-22.

30 Józef Maria Bocheński, Sens życia i inne eseje (Kraków: Wydawnictwo Philed, 1992), 2.

31 Jarosław Horowski, „Pedagogiczne implikacje analiz Józefa Marii Bocheńskiego”, w: Filozofia wychowania w praktyce pedagogicznej, red. Anna Szudra-Barszcz, Sławomir Sztobryn (Lublin: Wydawnictwo KUL, 2012), 154.

${ }^{32}$ Fragment wiadomości przesłanej do autorki bloga dla opiekunów osób chorych na demencje, 05.2015, cyt. za: opiekanadseniorami.blogspot.com [dostęp: 05.2015 r.], redakcja bloga: K. Kramkowska. 


\section{Wartości religijne i duchowe a sens życia}

Współczesne Polskie społeczeństwo, mimo dynamicznych zmian, jest uważane za religijne, z dominacją wyznań chrześcijańskich ${ }^{33}$. Warto za Piotrem Krakowiakiem przypomnieć, iż „duchowość” to pojęcie dotyczące najogólniej całej niematerialnej części rzeczywistości. Uniwersalną definicję duchowości podali uczestnicy spotkania dotyczącego poprawy jakości opieki duchowej jako istotnego elementu opieki paliatywnej w Stanach Zjednoczonych: „Duchowość jest aspektem człowieczeństwa, który odnosi się do sposobu, w jaki jednostki poszukują i wyrażają sens i cel oraz sposób, w który doświadczają własnej łączności z obecną chwilą, z sobą, z innymi, z naturą oraz ze wszystkim, co jest dla nich znaczące lub święte" ${ }^{34}$. Duchowe potrzeby posiada każda osoba, którą jako zespół otaczamy opieką; także ta, która deklaruje się jako niewierząca i niezwiązana z żadnym systemem religijnym. Termin ,religijność” pochodzi od łacińskiego terminu religio, utworzonego zarówno od czasownika religare - połączenie i ścisłe związanie z Bogiem, jak i relegere - pilne powtarzanie, a także przestrzeganie tego, co ma związek z czcią Boga ${ }^{35}$. Jak zauważył Arnaldo Pangrazzi, będący doświadczonym kapelanem i nauczycielem opieki duchowo-religijnej, wszędzie, gdzie pojawia się człowiek, rozwija się kultura, społeczeństwo i religia. Religijność to zbiór tradycji, rytów i prawd wiary, które przyjmujemy dzięki kulturowej przynależności do wspólnoty. Zależnie od miejsca urodzenia mamy tożsamość islamska, hinduska, buddyjską, żydowska, chrześcijańską ${ }^{36}$. Zarówno duchowni, jak i świeccy członkowie zespołów opiekuńczych, ale także opiekunowie rodzinni powinni - poprzez aktywne słuchanie i postawę pełną ak-

33 W Polsce katolicyzm wyznawało w 2011 roku 86,9\% Polaków, prawosławie - 1,31\%, protestantyzm - 0,38\%. Islam wyznaje $0,013 \%$, a judaizm jest religią $0,004 \%$ mieszkańców naszego kraju. Zob. Główny Urząd Statystyczny, Wyznania religijne i stowarzyszenia narodowościowe i etniczne w Polsce 2009-2011, źródło: http://www.stat.gov.pl/cps/rde/xbcr/gus/ oz_wyznania_religijne_stow_nar_i_etn_w_pol_2009-2011.pdf [dostęp: 2013 r.].

${ }^{34}$ Cyt. za: Piotr Krakowiak, „Zadania duszpasterzy i ich współpracowników w duchowo-religijnej opiece u kresu życia”, w: Edukacja terapeutyczna w hospicjum, red. Małgorzata Fopka-Kowalczyk, Teresa Łącka (Toruń: Stowarzyszenie Hospicjum „Światło”, 2013), 116.

35 Władysława Łydka, ,Religia”, w: Stownik teologiczny, red. Andrzej Zuberbier (Katowice: Księgarnia św. Jacka, 1989), 198.

${ }^{36}$ Arnaldo Pangrazzi, Vivere il tramonto. Paure, bisogni e speranze dinanzi alla morte (Tento: Erickson, 2006), 237. 
ceptacji - odpowiadać na potrzeby pacjentów ${ }^{37}$. W przypadku rodzin z chorym na demencje troska o potrzeby duchowo-religijne dotyczy w pierwszej kolejności członków rodzin, choć stwierdzono pozytywny wpływ rytuałów religijnych na pacjentów we wczesnych fazach chorób demencyjnych ${ }^{38}$. Zgodnie z tematyką tego doniesienia główny obszar badań jest związany $\mathrm{z}$ potrzebami członków rodzin.

Na rytualną i religijną stronę duchowości zwraca uwagę także Robert Emmons, który zakłada, że istnienie duchowych dążeń u człowieka, jako element procesu poszukiwania sensu, wiąże się z dobrostanem psychicznym. Wyodrębnił on także wskaźniki tych dążeń: doskonalenie wiedzy na temat sił wyższych - poszukiwanie Boga w życiu, pogłębianie wiedzy o swojej religii, utrzymywanie i pogłębianie kontaktu z siłą wyższą - rozwijanie wiary oraz wdrażanie w życie tego, w co się wierzy, a następnie życie zgodnie z Bożym prawem. Skupianie się na wyższych stanach emocjonalnych, dążenie do duchowego rozwoju wskazuje na znaczenie duchowości w życiu człowieka nie tylko w sensie teoretycznym, ale także w wymiarze praktycznym ${ }^{39}$.

Opiekunowie, podejmując wielorakie próby radzenia sobie z sytuacją długotrwałego stresu, zmęczenia i poczucia nieskuteczności, nadają sens własnemu działaniu także w obszarze duchowości i religijności. Punktem wyjścia do refleksji duchowej jest zazwyczaj stan zdrowia podopiecznego oraz zmiany w nim zachodzące. Duchowość należy rozumieć w tym miejscu nie tylko jako religijne rytuały, ale także jako pytania o etykę i rzeczy ostateczne ${ }^{40}$. Nieuchronność śmierci skłania do refleksji nad życiem po niej, jak również wartością doświadczonego cierpienia. Sytuacja ta paradoksalnie nie dotyczy zazwyczaj samego chorego, jak dzieje się to w przypadku innych chorób przewlekłych, jak na przykład choroby nowotworowej, ale rodziny, która - w przeciwieństwie do chorego - rozumie jego sytuację zdrowotna.

Wieloletni stresogenny proces chorobowy bliskiej osoby, zakończony jego zgonem, może być niewątpliwie kwalifikowany jako sytuacja traumatyczna. Jacek Norkowski pisze, że śmierć przychodzi tylko raz, ale czuje się ją w ciagu całego życia. Śmierć osoby bliskiej to ogromny wstrząs dla orga-

37 Por. Krakowiak, ,Zadania”, 113-146.

38 Océane Agli, Nathalie Bailly, ,Spirituality and religion in older adults with dementia: a systematic review", International Psychogeriatrics 5 (2015): 715-725.

39 Cyt. za: Katarzyna Skrzypińska, ,Dokąd zmierzam - duchowość jako wymiar osobowości”, Roczniki Psychologiczne 1 (2008): 46.

40 Piotr Krakowiak, Zdażyć z prawdą. O sztuce komunikacji w hospicjum (Gdańsk: Via Medica, 2009), 62. 
nizmu - nawet jeśli jesteśmy na nią przygotowani, a żałoba to droga, którą każdy przechodzi inaczej. Śmierć osoby bliskiej, nawet gdy opiekun zdaje się być na nią gotowy, jest ogromnym wstrząsem dla jego organizmu ${ }^{41}$. Pomimo uczestnictwa w chorobie osoby bliskiej, po jej kres pojawiają się pytania o przyczynę śmierci, o sens cierpienia i niepokój, czy uczyniło się wszystko, by temu odejściu zapobiec. Doświadczenie cierpienia, choć jest dotkliwe, daje szansę na nowe spojrzenie na własne życie ${ }^{42}$. Powyższe słowa pozwalają na pomoc opiekunom rodzinnym w odnajdowaniu sensu życia po obciążającej opiece i dotkliwej stracie.

\section{Poszukiwanie nowego sensu życia w rodzinach z chorymi demencyjnymi}

Wspomniany już Józef Maria Bocheński w książce Sens życia i inne eseje w odniesieniu do sensu życia i dążenia do celu tak pisze: „Kiedy twój sens życia jest zagrożony, staraj się znaleźć cel, do którego mógłbyś intensywnie dążyć. To rada, którą dałem niedawno na pół sparaliżowanemu przyjacielowi, zagrożonemu próżnią, jaką za sobą pociaga utrata sensu życia"43. Ta wydać się może prosta rada wpisuje się doskonale $\mathrm{w}$ istotę poszukiwania sensu życia przez opiekunów osób z chorobami demencyjnymi mózgu, w trakcie trwania choroby, a także po odejściu osoby bliskiej. Choroba członka rodziny dezorganizuje życie osobiste i rodzinne chorego, zmienia system wartości oraz wyznacza nowe cele. Zmiana stanu zdrowia to także nieustanny proces przemian w życiu opiekuna, w którym nietrudno zgubić główny cel i, co za tym idzie, sens życia. Każda sytuacja trudna nieść może za sobą destrukcyjne reakcje i skutki, ale także pozytywną transformację, by zaczać ,żyć od nowa”.

Termin „rozwój postraumatyczny” (posttraumatic growth) wprowadzili Richard Tedeschi i Lawrence Calhoun ${ }^{44}$ w nawiązaniu do poglądów Geralda Caplana oraz Victora Frankla, którzy wskazywali, że doświadczanie stre-

${ }^{41}$ Por. Jacek Norkowski, Człowiek umiera tylko raz (Warszawa: Wydawnictwo Thaurus, 2013).

${ }^{42}$ Sidnay Zisook, Katherine Shear, ,Grief and bereavement: what psychiatrists need to know", World Psychiatry 8 (2009): 67-74.

43 Józef Maria Bocheński, Sens życia i inne eseje (Kraków: Wydawnictwo Philed, 1993), 2.

${ }^{44}$ Richard Tedeschi, Lawrence Calhoun, ,The Post-Traumatic Growth Inventory: Measuring the positive legacy of trauma", Trauma Stress 9 (1996): 455-471. 
sujących wydarzeń może być powiązane z pojawianiem się pozytywnych zmian psychologicznych. Opisywali to zjawisko jako odkrycie znaczenia, pozytywne złudzenia, rozkwit, czerpanie siły z przeciwności czy transformacyjne radzenie sobie. Termin ,postraumatyczny rozwój” pełniej ujmuje istotę zjawiska niż wymienione pojęcia, będąc nie tylko stanem czerpania sił podczas trudnego życiowego okresu, ale także znaczącymi zmianami po jego zakończeniu. Badania amerykańskie dowodzą, że ponad 50\% kobiet i $60 \%$ mężczyzn badanych wskazuje na sytuację, która mieści się w ramach tego określenia. Wśród przywołanych zdarzeń znajduje się między innymi utrata osoby bliskiej, obserwowanie zgonu lub zranienia ${ }^{45}$.

Samo zjawisko rozpatruje się na kilku etapach. Wraz z pojawieniem się sytuacji traumatycznej zostaje całkowicie zaburzony obraz świata osoby, która tej traumy doświadcza. Wymusza to na jednostce weryfikację swoich podstawowych założeń na temat tego, kim jest, w jakim świecie żyje, jacy ludzie są w najbliższym otoczeniu i czego może się spodziewać w przyszłości. Kolejny etap to próba odbudowania swojej wizji świata i schematów poznawczych. To wszystko sprawia, że osoba doświadczająca traumy nieustannie wraca myślami do sytuacji, w jakiej się znalazła, i dokonuje przetwarzania poznawczego o charakterze ,nadawania sensu, rozwiazzywania problemu, wydobywania wspomnień i formułowania oczekiwań" ${ }^{46}$. Możemy w tym dostrzec analogię do definicyjnej formy rozumienia nadawania sensu życiu i poszukiwaniu tego sensu. Wyjście z traumy to nie tylko trud samej osoby doświadczającej sytuacji trudnej, ale także otwarcie się na pomoc specjalistów i wsparcie najbliższego otoczenia. Wsparcie to powinno zostać udzielone możliwie jak najszybciej, profilaktycznie.

Opiekun zazwyczaj nie jest osobą przygotowaną do uczestniczenia w życiu osoby u jej kresu, dlatego kluczowym punktem w opiece nad chorym jest edukacja rodziny i jej kręgu, mająca na celu przygotowanie ich na szereg sytuacji trudnych będących częścią ich codziennego życia. Wsparcie i edukacja odbywają się na wielu płaszczyznach, od psychologicznej, poprzez praktyczne nauczanie czynności pielęgnacyjnych, aż po duchowe przygotowanie do zgonu oraz życia w okresie żałoby. Wsparcie i edukacja

45 Maria Lis-Turlejska, „Zdarzenia traumatyczne - sposoby definiowania, pomiar i rozpowszechnienie", w: Konsekwencje psychiczne traumy, red. Jan Strelau, Bogdan Zawadzki (Warszawa: Wydawnictwo Naukowe SCHOLAR, 2009), 15-33.

46 Richard Tedeschi, Lawrence Calhoun, „Podejście kliniczne do wzrostu po doświadczeniach traumatycznych", w: Psychologia pozytywna w praktyce, red. Alex Lindley (Warszawa: Wydawnictwo Naukowe PWN, 2007), 230-248. 
mają także duży wpływ na jakość życia członków rodziny po doświadczeniu straty bliskiej osoby ${ }^{47}$. W sytuacji, w której działania nie mogą mieć już charakteru profilaktycznego, wsparciem dla osób poszukujących punktu stycznego z życiem obecnym i przyszłym - ,nowym”, powinno być wieloaspektowe wsparcie udzielone holistycznie w różnych obszarach problemu, z którym boryka się opiekun. Poszukując ośrodków wsparcia, spotkać można wiele miejsc - instytucji pomagających zaczać życie od nowa, po wielu trudnych sytuacjach: wypadkach komunikacyjnych, przemocy w rodzinie, alkoholizmie, nowotworze złośliwym, gwałcie i nadużyciu seksualnym, przestępstwie czy trudnym dzieciństwie, w tym kontekście nie znajdziemy niestety wsparcia dla osób po długoletniej opiece nad chorym z zaburzoną świadomością w chorobach demencyjnych. Ośrodki i Towarzystwa Alzheimerowskie coraz częściej wychodzą naprzeciw temu problemowi, nadal jednak bardzo wielu opiekunów nie wie, że istnieje taka możliwość.

O potrzebie takiej przestrzeni wyrażania siebie i poszukiwania sensu świadczyć może przykład bloga ${ }^{48}$, którego miesięcznie odwiedza blisko trzy tysiące osób. Duża grupa zadaje pytania o możliwość wsparcia lub wprost zwierza się autorce z problemów i codziennych trosk, podkreślając, że nie znajdują wsparcia i zrozumienia w tak zwanym realnym życiu. Korespondencja niejednokrotnie jest cykliczna, odnosząca się do szczegółów z dnia codziennego, emocji, wspomnień, przemyśleń dotyczących bieżących sytuacji, poszukiwania sensu w chwilach zwątpienia. Autorzy wiadomości czasem po kilku miesiącach, kiedy silne emocje opadna, informują, jak toczą się ich losy i jak odnajdują się w nowej rzeczywistości. Oto przykład: „Pomalutku składam wszystkie swoje dni i staram sie dalej żyć. Będzie to inne życie, ale wierzę, że mama jest ze mną i zawsze będzie w moim sercu, a tacy ludzie nigdy nie umierają"49. Potrzeba dzielenia się bardzo osobistymi sprawami, intymnymi sytuacjami, emocjami z zupełnie obcą osobą pokazuje, jak wielka jest potrzeba uzyskania wsparcia. Chodzi czasem tylko o zapewnienie, że to, co się robi wobec chorego, jest dobre i słuszne, a życie bez niego będzie możliwe. Obecność innych ludzi, udzielających wsparcia na miarę potrzeb

47 Por. Piotr Krakowiak, Strata, osierocenie i żałoba. Poradnik dla pomagajacych i dla osób w żałobie (Gdańsk: Via Medica, 2007).

${ }^{48}$ Fragment wiadomości przesłanej do autorki bloga dla opiekunów osób chorych na demencje, cyt. za: opiekanadseniorami.blogspot.com [dostęp: 10.2015 r.], redakcja bloga: K. Kramkowska.

49 Tamże [dostęp: 12.2015 r.]. 
opiekuna, staje się tym samym warunkiem koniecznym dla powrotu do równowagi i odnalezienia celu w dalszym życiu.

\section{Zakończenie}

Poszukiwanie wartości i sensu życia w rodzinie doświadczającej przewlekłych chorób demencyjnych mózgu jest wyzwaniem od chwili diagnozy, poprzez stopniową deteriorację bliskiej osoby, aż do śmierci i osierocenia. Sens życia podlegać będzie w tym okresie nieustannym zmianom w swym dynamicznym charakterze, nie przestając istnieć sam w sobie. Życie ludzkie, szczególnie w sytuacji kryzysowej, którą jest przewlekła choroba w rodzinie, jest tym samym pasmem zadań do realizacji, z możliwością nadania własnego sensu zastanym i kreowanym wydarzeniom. Człowiek osadzony w świecie wartości ma możliwość ujawniania wciąż nowych zasobów życia duchowego oraz odnajdowania sensu życia nawet w tak dramatycznych okolicznościach, jak choroba demencyjna ukochanej osoby. Umiejętne wsłuchanie się $\mathrm{w}$ świat wartości opiekunów rodzinnych w przypadku profesjonalistów ochrony zdrowia i pomocy społecznej jest ważnym elementem wsparcia. Sztuka komunikacji w odniesieniu do rodzin osób chorych na demencje wiąże się przede wszystkim z umiejętnością wysłuchania ich obaw i trosk o bliską osobę, będącą tylko fizycznie obecną ${ }^{50}$. Podobnie jak $\mathrm{w}$ innych chorobach u kresu życia opiekunowie rodzinni wymagają wsparcia i opieki wyręczającej. Także duchowo-religijne wartości mogą dać opiekunom rodzinnym świadomość bycia wciąż osadzonym w życiu sensownym i wartościowym, co stać się może punktem wyjścia do osobistego namysłu nad tym, co jest ważne ${ }^{51}$. Współpraca opiekunów ochrony zdrowia i pomocy społecznej oraz troska o bliskich osób ciężko chorych na demencje staje się kolejnym pilnym wyzwaniem społecznym. Prezentowane tu zagadnienie poszukiwania sensu życia nie powinno być obojętne dla badaczy i praktyków nauk społecznych, jak również wszystkich osób z humanistyczną i chrześcijańską wrażliwością. Kolejne doniesienia i badania, a także praktyczne

50 Anna Janowicz, Piotr Krakowiak, Zdrowa rozmowa. Sztuka komunikacji w opiece u kresu życia (Gdańsk: Via Medica, 2014).

${ }^{51}$ Piotr Krakowiak „Duchowo-religijna troska o ciężko i przewlekle chorą osobę”, w: Przewlekle chory w domu, red. Piotr Krakowiak, Dominik Krzyżanowski (Gdańsk: Via Mediaca, 2011), 347-371. 
wdrożenia opieki wytchnieniowej dla rodzin chorych na demencje są pilną potrzebą społeczną w naszych kraju.

\section{The Search for the Meaning of Life in a Family of a Person Experiencing Chronic Dementia Diseases of the Brain (Summary)}

Old age and dependence, as well as the dramatic struggles of a growing number of families of the seriously ill to care for them at home, are problems which are discussed to rarely in the social sciences. An increase of dementia diseases both in Poland and in Europe is being predicted by demographers. Because of the heterogeneity of clinical symptoms and frequent need to exercise care at home, these diseases pose a particular challenge for family caregivers. The family is the main subject of the struggle with long-term dementia of one of its members. A sense of responsibility for a family member in the course of care and an experience of his/her emotional departure into different reality, affects the meaning of life. This kind of experience leads caregivers to reflect on their own existence and its meaning. There are existential and spiritual questions appearing, and often the whole family or its members are permanently stigmatized with the illness of dementia. The specific situation of a family, which is the interaction with a person with cognitive impairment and limited awareness, leads to adopting new values of care and searching for the sense of life. Considerations about the changes in the family system and the world of values will be analyzed in the light of the new roles of family affected by dementia. The selected classics of existential philosophy and personalism will give a lead in finding values and meta-values and attempting to understand and find the meaning of life in families experiencing dementia of one of their member. Researchers and practitioners of the social sciences and, particularly, childcare education and social work do need further research and practical tools to obtain assistance in the search for the meaning of life in families affected by dementia of one of their members. Tools for practical support for family caregivers are also needed.

Key words: values and the meaning of life; family; chronic dementia; family care; spiritual and religious care. 


\section{Poszukiwania sensu życia w rodzinie osoby doświadczającej przewlekłych chorób demencyjnych mózgu (Streszczenie)}

Starość i niesamodzielność, jak również dramatyczne zmagania coraz większej liczby rodzin osób ciężko chorych o opiekę nad nimi w warunkach domowych, to problemy, o których mówi się za mało w naukach społecznych. Wzrost chorób demencyjnych prognozują demografowie zarówno w Polsce, jak i w Europie, a ze względu na niejednorodność kliniczną w zakresie objawów i konieczność sprawowania opieki w domu - stanowią one szczególne wyzwanie dla opiekunów rodzinnych. Rodzina jest najczęściej głównym podmiotem zmagania się z długoletnią chorobą demencyjną jednego z jej członków. Poczucie odpowiedzialności za bliską osobę $\mathrm{w}$ toku sprawowanej opieki i przeżywanie jej emocjonalnego odchodzenia w inną rzeczywistość wpływają na poczucie sensu życia. Tego rodzaju doświadczenia prowadzą opiekunów do refleksji dotyczącej własnej egzystencji i sensu istnienia. Pojawiają się pytania egzystencjalne oraz duchowe, a często życie całej rodziny i poszczególnych osób zostaje trwale naznaczone znamieniem choroby demencyjnej bliskiego. Specyficzna sytuacja rodzinna, jaką jest współdziałanie z osobą z zaburzeniami poznawczymi i ograniczoną świadomościa, prowadzi do nadawania nowych wartości opiece i własnemu życiu. Rozważania o tych zmianach w systemie rodzinnym oraz świecie wartości zostaną podjęte w świetle nowych ról rodzinnych i społecznych we wspólnotach rodzinnych dotkniętych chorobą demencyjną. W rozważaniach na gruncie filozofii wybrani klasycy filozofii egzystencjalnej i personalizmu będą przewodnikami w poszukiwaniu wartości i metawartości oraz próbach zrozumienia sensu życia wobec doświadczenia chorób demencyjnych w rodzinie. Badacze i praktycy nauk społecznych, a szczególnie pedagogiki opiekuńczej i pracy socjalnej, potrzebują dalszych badań i praktycznych narzędzi, by pomóc w poszukiwaniu sensu życia w rodzinach dotkniętych chorobą demencyjną jednego $\mathrm{z}$ ich członków oraz praktycznie wspierać opiekunów rodzinnych.

Słowa kluczowe: wartości i sens życia; rodzina; przewlekłe choroby demencyjne mózgu; opieka rodzinna; opieka duchowo-religijna.

\section{Bibliografia}

Adamski, Franciszek. Rodzina, wymiar społeczno-kulturowy. Kraków: Wydawnictwo Uniwersytetu Jagiellońskiego, 2002. 
Agli, Océane, Nathalie Bailly. „Spirituality and religion in older adults with dementia: a systematic review". International Psychogeriatrics 5 (2015): 715-725.

Barcikowska, Maria. Rozpoznawanie i leczenie otępień. Rekomendacje Interdyscyplinarnej Grupy Ekspertów Rozpoznawania i Leczenia Otępień. Lublin: Igero, 2006.

Benedykt XVI. Encyklika Spe Salvi. Watykan: Libreria Editrice Vaticana, 2007.

Biernat, Tomasz. „Czy istnieje rodzina ponowoczesna?”. Pedagogia Christiana 2 (2014): 183-195.

Biernat, Tomasz. „O przemianach definicji rodziny i ich konsekwencjach”. Społeczeństwo i Rodzina 18 (2009): 28-40.

Blackburn, Simon. Oksfordzki stownik filozoficzny. Warszawa: Książka i Wiedza, 1997.

Blog: opiekanadseniorami.blogspot.com, redakcja bloga: Karolina Kramkowska.

Bocheński, Józef Maria. Podręcznik mądrości tego świata. Kraków: Wydawnictwo Philed, 1992.

Bocheński, Józef Maria. Sens życia i inne eseje. Kraków: Wydawnictwo Philed, 1993.

Bradshaw, John. Zrozumieć rodzinę. Warszawa: IPZiT, PTP, 1994.

Dolata, Marek. „Sens życia jako problem etyki”. W: Etyka i sens życia, red. Dorota Probucka, 59-68. Kraków: WNUP, 2011.

Elzenberg, Henryk. Z filozofii kultury. Kraków: Znak, 1991.

Gabrylewicz, Tomasz. „Konsekwencje zdrowotne i społeczne łagodnych zaburzeń poznawczych". W: Choroby otepienne. Teoria i praktyka, red. Jerzy Leszek, 365-373. Wrocław: Continuo, 2003.

Główny Urząd Statystyczny. Wyznania religijne i stowarzyszenia narodowościowe i etniczne w Polsce 2009-2011. Warszawa: GUS, 2013.

Grochmal-Bach, Bożena. Cierpienie osób z otępieniem typu Alzheimera. Kraków: WAM, 2007.

Horowski, Jarosław. „Pedagogiczne implikacje analiz Józefa Marii Bocheńskiego”. W: Filozofia wychowania w praktyce pedagogicznej, red. Anna Szudra-Barszcz, Sławomir Sztobryn, 143-167. Lublin: Wydawnictwo KUL, 2012.

Jakubiec, Sebastian. Mediacje jako metoda pracy z rodzinq. Kraków: WSFP Ignatianum, 2011.

Janowicz, Anna, Piotr Krakowiak. Zdrowa rozmowa. Sztuka komunikacji w opiece u kresu życia. Gdańsk: Via Medica, 2014.

Janowicz, Anna. „Rola opiekunów nieformalnych w opiece u kresu życia. Przyczynek do badań w ramach projektu European Palliative Care Academy (EUPCA)". Pielegniarstwo i Zdrowie Publiczne 2 (2014): 161-167. 
Kłoszewska, Iwona. „Rola opiekuna chorych z otępieniem”. Polski Przeglad Neurologiczny 2 (2007): 105-109.

Kołakowski, Leszek. Światopoglad i życie codzienne. Warszawa: PIW, 1975.

Kotarbiński, Tadeusz. Medytacje o życiu godziwym. Warszawa: Wiedza Powszechna, 1966.

Krakowiak, Piotr. „Duchowo-religijna troska o ciężko i przewlekle chorą osobę”. W: Przewlekle chory w domu, red. Piotr Krakowiak, Dominik Krzyżanowski, 347-369. Gdańsk: Via Mediaca, 2011.

Krakowiak, Piotr. „Zadania duszpasterzy i ich współpracowników w duchowo-religijnej opiece u kresu życia". W: Edukacja terapeutyczna w hospicjum, red. Małgorzata Fopka-Kowalczyk, Teresa Łącka, 113-146. Toruń: Stowarzyszenie Hospicjum „Światło”, 2013.

Krakowiak, Piotr. Strata, osierocenie $i$ żałoba. Poradnik dla pomagajacych $i$ dla osób w żałobie. Gdańsk: Via Medica, 2007.

Krakowiak, Piotr. Wolontariat w opiece u kresu życia. Toruń: Wydawnictwo Naukowe Uniwersytetu Mikołaja Kopernika, 2012.

Krakowiak, Piotr. Zdażyć z prawdq. O sztuce komunikacji w hospicjum. Gdańsk: Via Medica, 2009.

Lis-Turlejska, Maria. ,Zdarzenia traumatyczne - sposoby definiowania, pomiar i rozpowszechnienie". W: Konsekwencje psychiczne traumy, red. Jan Strelau, Bogdan Zawadzki, 15-35. Warszawa: Wydawnictwo Naukowe SCHOLAR, 2009.

Łydka, Władysław. „Religia”. W: Słownik teologiczny, red. Andrzej Zuberbier, 198-205. Katowice: Księgarnia św. Jacka, 1989.

Norkowski, Jacek. Człowiek umiera tylko raz. Warszawa: Wydawnictwo Thaurus, 2013.

Oleś, Piotr. Wprowadzenie do psychologii osobowości. Warszawa: Wydawnictwo PWN, 2003.

Ostrowska, Urszula. „Aksjologiczne podstawy wychowania”. W: Pedagogika: podstawy nauk o wychowaniu, t. 1, red. Bogusław Śliwerski, 391-415 Gdańsk: Gdańskie Wydawnictwo Psychologiczne, 2006.

Pangrazzi Arnaldo. Vivere il tramonto. Paure, bisogni e speranze dinanzi alla morte. Tento: Erickson, 2006.

Rzecznik Praw Obywatelskich. Sytuacja osób chorych na chorobę Alzheimera w Polsce. https://www.rpo.gov.pl/sites/default/files/Sytuacja\%20os $\% \mathrm{C} 3 \% \mathrm{~B} 3 \mathrm{~b} \% 20$ chorych\%20na\%20chorob\%C4\%99\%20Alzheimera\%20w\%20Polsce\%20Raport\%20RPO.pdf [dostęp: 12.2015 r.].

Skrzypińska, Katarzyna. „Dokąd zmierzam - duchowość jako wymiar osobowości”. Roczniki Psychologiczne 1 (2008), 39-57. 
Tedeschi, Richard, Lawrence Calhoun. „Podejście kliniczne do wzrostu po doświadczeniach traumatycznych". W: Psychologia pozytywna w praktyce, red. Alex Lindley, 230-248. Warszawa: Wydawnictwo Naukowe PWN, 2007.

Tedeschi, Richard, Lawrence Calhoun. „The Post-Traumatic Growth Inventory: Measuring the positive legacy of trauma". Trauma Stress 9 (1996): 455-471.

Terelak, Jan. „Przeciążenie jako źródło stresu”. W: Psychologia stresu, red. Jan Terelak, 190-194. Bydgoszcz: Oficyna Wydawnicza BRANTA, 2001.

Tyszka, Zbigniew. „Rodzina w świecie współczesnym - jej znaczenie dla jednostki i społeczeństwa”. W: Pedagogika społeczna, red. Tadeusz Pilch, Irena Lepalczyk, 137-154. Warszawa: Żak, 1995.

Tyszka, Zbigniew. Socjologia rodziny. Warszawa: PWN, 1974.

World Health Organization, Alzheimer's Disease International. Dementia - a public health priority. Genewa: World Health Organization, 2012.

Ziemska, Maria. Rodzina a osobowość. Warszawa: Wiedza Powszechna, 1979.

Zisook, Sidnay, Katherine Shear. „Grief and bereavement: what psychiatrists need to know”. World Psychiatry 8 (2009): 67-74. 